\title{
Perceived Fairness of Performance Appraisal, Promotion Opportunity and Nurses Turnover Intention: The Role of Organizational Commitment
}

\author{
Mohammad Rabiul Basher Rubel ${ }^{1,2}$ \& Daisy Mui Hung Kee ${ }^{1}$ \\ ${ }^{1}$ School of Management, Universiti Sains Malaysia, Penang, Malaysia \\ ${ }^{2}$ Department of Business Administration, Stamford University Bangladesh, Dhaka, Bangladesh \\ Correspondence: Mohammad Rabiul Basher Rubel, School of Management, Universiti Sains Malaysia, Penang, \\ 11800, Malaysia. E-mail: asstprof_sub@yahoo.com
}

Received: October 19, $2014 \quad$ Accepted: November 25, $2014 \quad$ Online Published: April 2, 2015
doi:10.5539/ass.v11n9p183

\begin{abstract}
The purpose of this study is to examine the effect of the performance appraisal fairness and promotion opportunity on employee quitting intention with the mediating effect of organizational commitment. A cross-sectional design was employed to investigate the relationship in a sample of 150 full-time nurses employed in different private hospitals. Partial Least Square path modeling, a variance based techniques of SEM was employed to test the proposed hypotheses. The results indicate the significant negative effects of perceived fairness of performance appraisal and promotion opportunity on nurses' quitting intention and organizational commitment. Further, organizational commitment is found having a significant effect on nurses' turnover intention and as a partial mediator in the relationship between both performance appraisal fairness and nurses' turnover intention and promotion opportunity and nurses' turnover intention.
\end{abstract}

Keywords: performance appraisal fairness, promotion opportunity, organizational commitment, turnover intention, nurses

\section{Introduction}

Since human capital is the key element that drives the growth of an organization, the ability of an organization in sustaining its human resources will bring greater rewards and success to the organization itself. High performers are very much sought after by all organizations to meet their goals, deliver the specialized products and services and eventually to gain competitive edge to be the leading organization in the industry. It is worth mentioning here that most organizations are fully aware of the high cost of turnover and expect even higher costs to skilled-performers turnover. For example, the inescapable nursing shortage and nurses' high turnover rate have become a critical issue (Kingma, 2001). Globally, nurse turnover rate ranges from 10-21\% per year across the countries (El-Jardali, Dimassi, Dumit, Jamal, \& Mouro, 2009). These nursing shortages and high turnover are symptoms of the health care problems of many hospitals across the globe (Rahman et al., 2010; Hayes et al., 2006). Therefore, research that focuses on the nurses turnover intention has the potential to produce a more comprehensive and realistic understanding of nurses turnover. The dearth of qualified health workers, specifically in low-income countries like Bangladesh has drawn consideration in recent times as it seriously pressurizes the achievement of the millennium development goals (Global Health Watch, 2005). Only 0.18 million nurses are available to serve 140 million people, which is a high potential threat to quality services for the patients in Bangladesh (Bangladesh Bureau of Statistics, 2012). Hospitals in Bangladesh have been suffering from high nurse turnover (Alam \& Shasi, 2012). Nurses' absenteeism rate reported is $27 \%$ (Chaudhury, Hammer, Kremer, Muralidharan, \& Rogers, 2006) but Ministry of health and family welfare of government republic of Bangladesh only reveals that nurse turnover rate is approximately 15\% (Bangladesh Bureau of Statistics, 2012). High turnover rates are reflective of low organizational commitment and possible indicator of an unhappy workforce in the hospitals. High turnover rates eventually lead to a broader issue. It also means that the hospitals do not have their best staff available. An overall shortage of health care employees, especially nurses and their turnover rates are alarming for the hospitals to provide better services to the patients (Ahmed, Hossain, Raja Chowdhury, \& Bhuiya, 2011). Hence we propose that adoption of proper human resource management (HRM) 
practices is a key determinant for organization success in the industry (Rubel \& Kee, 2013). Keeping a pool of valuable human resources via positive human resource practices is a critical issue today.

In Bangladesh, Hossain (2008) finds 63\% nurses are dissatisfied with their jobs which results low attachment to the organization and frequent job search behavior. Huge nurse shortage with elevated dissatisfaction is marked for their quitting intention and actual turnover in Bangladesh by the local researchers (Hossain, 2008; Alam \& Shasi, 2012). These researchers recommend hospitals should identify the strategies to reduce nurse turnover behavior as well as to minimize the shortage by attracting new nurses as they are valuable human resources for hospitals. Local hospitals should give due attention on attracting and retaining their valuable nurses to make up nurses' talent shortages and the increasing demand for nurses. Keeping this urge in mind, we focus the present study on nurses' quitting intention in Bangladesh. Previous research found the most common predictor of nurses' quitting intention are job dissatisfaction (Liu et al., 2012; Morrell, 2005); low organizational commitment (Chang, 2007), demographic characteristics (Nogueras, 2005), unethical climate (Hwang \& Chang, 2009) and lack of empowerment (Cai \& Zhou, 2009). In this study, we attempt to link the HRM practices with nurses' turnover intention and provide hospitals some new insights to retain these valuable talents.

Bartram et al. (2012) in their research, suggest that future research should examine the impact of HRM practices on organizational outcome such as organizational commitment and quitting intention. In this paper, we build upon this line of research and focus on two main HRM practices namely, performance appraisal fairness and promotion opportunity. Relatively few studies were conducted to investigate the relationship between specific HRM practice and employee outcomes (Haines et al., 2010) rather than investigating bundles of practices (Yalabik, Chen, Lawler, \& Kim, 2008). Prior researches have not devoted much attention to specific HRM practice in the context of nurses' turnover study particularly in large private hospitals. We assume that specific HRM practices would have a different predicting mechanism on nurses quitting intention. In addition, little was done specifically to integrate both organizational justice and HRM practices and their outcomes in the organization. This paper attempts to examine performance appraisal fairness in the light of organizational justice and its impact on turnover intention. Specifically we assume that perceived fairness of performance appraisal and promotion opportunity will have a negative impact on nurse quitting intention through the mediating effect of organizational commitment. This relationship is presented in Figure 1.

Further, extensive research on nurse quitting intention and intent to stay comes from studies of nurses working mainly in Western countries (Liu et al., 2012). A gap in existing literature considering nurse quitting intention in developing country context is identified (Ahmed et al., 2011). Moreover, in the context of Bangladesh, the focus on HRM practices and nurse turnover and turnover intention is the gap in the previous literature (Alam \& Shahi, 2012; Hossain, 2008). Therefore, this study intends to fulfill this gap.

\section{Theoretical Basis}

Social Exchange Theory (SET) provides a theoretical ground towards the understanding and prediction of the relationship between perceived fairness of performance appraisal, promotion opportunity and organizational commitment on nurses quitting intention. The fundamental premise of SET is that, human behavior is an exchange of rewards between actors (Zafirovski, 2005) and exchange characterizes all human interactions (Homans, 1958). In other words, individuals cooperate to each other based on a self-interested analysis of the costs and benefits. Blau (1964) defines social exchange as the voluntary actions of individuals driven by the expected returns they will receive as a result of their voluntarily-initiated behaviors. As the objective of the present study is to examine the relationship between perceived fairness of performance appraisal, promotion opportunity and organizational commitment on nurses quitting intention, SET is applicable in this context. Employing psychological contract context, Kee, Ansari and Aafaqi (2004) suggest fairness in HRM practices indicate the nature of the relationship that employees can expect to get from their organization. They further argue reciprocity norms between management and employees is indicative of an investment in the organization on behalf of employees is a fair trade for an investment in employees on behalf of the organization.

Building on SET, we suggest employees' perception of fairness of HRM practices leads individuals to be more inclined to attach with the organization. We therefore expect that organizational commitment is a channel through which employees may reciprocate or return the favor rendered through HRM practices by employers who well-treat their employees. These favors on the part of employer cause an obligation on the part of employees to reciprocate through organizational commitment towards the organization and thus reduce their thought of quitting. 


\section{Literature Review and Hypothesis}

\subsection{Performance Appraisal Fairness}

HRM practices are practices used by the organization to attract, motivate and retain its employees to achieve its goals and operational objectives (Lepak \& Gowan, 2010). HRM practice is the primary mean by which organizations can control the attitudes and behavior of their employees to perform their own responsibility and thus, achieve organizational goals (Collins \& Clark, 2003). In this paper, we focus on performance appraisal fairness and promotion opportunity. One key reason performance appraisal is chosen because it is one of the main HRM practices to measure the effectiveness and efficiency of employee performance (Redman, Snape, Thompson, \& Yan, 2000). Performance appraisal as a component of HRM practices acknowledges the contribution of individual employee and makes each employee more committed to the organization (Armstrong-Stassen \& Schlosser, 2010). Performance appraisal enables both the organization and the employees to recognize, evaluate and develop an individual's standard of performance (Ikramullah, Shah, Khan, Hassan, \& Zaman, 2012) and to encourage poor performer to improve (Scott \& Einstein, 2001). Thus, it is vital for the organization to make performance appraisal to be more accurate, accepted and fair for the employee improvement.

Still, researchers argue individual performance appraisal presume a questionable issue based on the measurement accuracy and fairness (Boxall \& Purcell, 2003; Swiercz, Bryan, Eagle, Bizzotto, \& Renn, 2012). Very little evidences have been found on performance appraisal fairness (Swiercz et al., 2012). Most of these deliberate the influences of either procedural or distributive fairness perceptions of employees or rarely both (Korsgaard \& Roberson, 1995). Moreover, in nursing area performance appraisal fairness was ignored in the previous literature. Therefore, performance appraisal fairness, considering procedural and interactional fairness and influencing nursing quitting intention is the research gap in the previous studies.

We conceptualize performance appraisal fairness as the extent to which employees perceive their organization conducts appraisal in a fair manner that emphasizes the delivery of their skills and work behaviors. Employee perceived performance appraisal fairness has also considerable impact on employee attitude and behavior (Boxall \& Purcell, 2003). Fairness of performance appraisal is highly emphasized by different authors who asserted that fairness in performance appraisal strengthens the feeling of employee about the organization and pursue them to be more productive (Korsgaard \& Roberson, 1995). The psychological experience of fairness leads individuals to be more committed to the organization and limit their thinking of quitting and alternative job search behavior (Ikramullah et al., 2012). Therefore, successful performance appraisal depends on the appraiser's perception of fairness regarding the appraisal system (Jawahar, 2007).

Researchers in performance appraisal have revealed well designed and fair performance appraisal system can attract, motivate as well as improve the performance of the employees (DeNisi \& Pritchard, 2006; Roberson \& Stewart, 2006). Moreover, a study carried out by Lau and Moser (2008) has found that an employee who believes the procedures are fair in measuring performance also experiences a higher level of commitment and consequently performs better. Previous studies also support the notion that fairness of performance appraisal is prominently related to employees' satisfaction, commitment, and motivation (Salleh, Amin, Muda, \& Halim, 2008). Kee et al. (2004) claim that perceived fairness in performance management and promotion negatively relate with continuance commitment. They argue those individuals who perceive performance management and promotion as fair may recognize greater cost associated with quitting the organization. Thus, from the literature the following hypothesis can be developed:

Hypothesis 1: Fairness in performance appraisal is positively related to nurse organizational commitment.

Whiting and Kline (2007) reveal dissatisfaction with performance appraisal induces employee's intention to quit. This relationship was also justified by Guchait and Cho (2010) who assert performance appraisal is one of the prime components of HRM which explains a significant negative relationship with quitting intention. In nursing study, performance evaluation is considered as a component of job satisfaction affecting nurse quitting intention (Tsai \& Wu, 2010). They find that well accepted performance evaluation increases nurse job satisfaction and reduces their quitting intention. Based on the same ground, other research also suggests appropriate implementation of performance appraisal as a HRM practice to attract, motivate and retain talented nurses in the organization (Armstrong-Stassen \& Schlosser, 2010). Ansari, Kee and Aafaqi (2000) in their findings indicate that fairness perception of HRM practices has strong negative impact on the intention to quit. They also claim that performance management and promotion seem to have the similar trend. Corollary to this idea, we believe it is possible that nurses' perception of fairness towards organizational practice such as performance appraisal influence nurses' intent to quit negatively. We, therefore, can present the following hypothesis: 
Hypothesis 2: Fairness in performance appraisal is negatively related with nurse turnover intention.

\subsection{Promotion Opportunity}

For most workers, provisions of employment such as rewards, benefits, and work atmosphere are enormously important features of a job. Also of importance is an individual's advancement opportunity within an organization. Rosen (1986) exhibits promotion opportunity within the firm as a tournament. A promotion is the "prize," and the likelihood of gaining commitment to the organization. Better promotion opportunity enhances the chances of receiving more salary, benefits, and prestige allied with the advanced position. In an earlier study, Holtom et al. (2008) reveal that promotion opportunity acts as a mechanism for increasing the sense of belongingness and commitment to the organization and consequences is the long term attachment with the organization.

In this paper, we conceptualize promotions (or advancements) opportunity as an incentive provided to employees when they display satisfied work behavior in the organization. Dessler (2009) clarifies that promotion occurs when an employee makes a shift in the upward position in organizational hierarchy and moves to a place of greater responsibility. Promotion is outlined as a career associated organizational improvement (Carson, et al., 1994). The authors denoted promotion as individual deliberately experiencing progression in the organizational hierarchy. Naveed, Usman, and Bushra (2011) explain that promotion indicates the expansion of the position of an employee in the external environment and realizes his worth in the internal environment. Promotion is a mechanism assuring the employee to escalate his/her position within the organization based on his or her performance and effort (Kosteas, 2011). A recent study on HRM practices and employee attitudes and behavior by Kehoe and Wright (2013) finds the significant influence of promotion opportunity on employee commitment in the organization. The authors reveal that on time and smooth career advancement scope in the organization pursue the employee to be more committed and loyal to the organization.

A recent study finds promotion opportunity in the organization along with other predictors of job satisfaction shows a substantial effect on employee's commitment to the organization (DeConinck \& Bachmann, 2011). This is also contemplated as a significant contributor to enhance nurse commitment to the organization. For instance, researchers reveal on time opportunities for promotion and its implementation enhance both the level of satisfaction and commitment of nurses in the organization (McNeese-Smith, 2001). In a recent study, Wang, Ellenbecker, and Liu (2012) find a positive relationship between promotion opportunity and nurse organizational commitment and reveal that suitable criteria for development within the organization increases nurses' commitment and responsibility. Further in another study, Rubel and Kee (2013) consider promotion opportunity is one of the indispensible constructs of HRM practices to induce the employee commitment to the organization. Supporting to this background, we propose the following hypothesis:

Hypothesis 3: Promotion opportunity is positively related to nurse organizational commitment.

The negative relation between promotion opportunity and quitting intention is found among employees of different organizational settings, for instance, jail officer (Kiekbusch, Price, \& Theis, 2003), banking employees (Ali \& Baloch, 2010), and teachers (Joarder, 2012). In an earlier study, Milkovich and Newman (1993) have acknowledged that promotion is positively related with salary growth of employees and negatively influence quitting intention. In nursing study, dissatisfaction with promotion and training opportunities is found having stronger effect than workload and pay on nurse turnover (Shields \& Ward, 2001). Further in a multivariate analysis, Beecroft, Dorey and Wenten (2008) include opportunities for advancement and promotion as satisfactory work environment variables influencing nurses' quitting intention.

Tsai and $\mathrm{Wu}$ (2010) measure promotion opportunity as a determinant of job satisfaction and find it significantly and negatively related with quitting intention. The authors reveal that specific guideline regarding career development opportunity in the organization increases their satisfaction and belongingness to the organization the consequence of which is less job search behavior. Rosen, Stiehl, Mittal and Leana (2011) find a significant negative relationship between promotion opportunity and nurse's quitting intention and actual turnover. They reveal that the switcher is more likely to report little promotion opportunity as one of the main reasons for turnover. In another study, Kim (2012) exposed that promotion opportunity is one of the important components of HRM practices having significant negative influence on state government IT employee's turnover intention. Kehoe and Wright (2013) also find the influence of promotion opportunity on employee turnover intention and clarify that lack of promotion opportunity reduces the commitment of employees and their intention to stay in the organization. Thus, we can hypothesize that

Hypothesis 4: Promotion opportunity is negatively related with nurse turnover intention. 


\subsection{Organizational Commitment as Mediator}

Chang (1999) advocated that to recognize how organizations stimulate employees one should believe the role of individual attitudes concerning careers or a certain line of work. Her interpretation clarifies that people with high level of commitment to their occupation will anticipate more from their organization and the extent to which those anticipations are met will ascertain their relationship with the employers. Organizational commitment has been the subject of several critical reviews of management and organizational behavior in earlier research (Meyer et al., 2002). Meyer and Allen (1991) outline commitment consisting of three dimensions, namely, affective, normative and continuance commitment. Affective commitment is defined as the relative strength of an individual's identification with and commitment to an organization. Again continuance commitment is the extent to which a person needs to stay with the organization, due to the costs of foregoing benefits associated with an individual's investment in the organization (Allen \& Meyer, 1990). And finally, normative commitment is the extent of which a person is obligated to stay with the current organizational settings (Meyer \& Allen, 1991). Overall, organizational commitment is the outcome of the employee organization relationship (Loi, Hang-Yue, \& Foley, 2006). It indicates the potentiality of an individual involvement in and identity with the distinct organization (Mowday, Steers, \& Porter, 1979).

It also measures employee loyalty to the organization (Yang, Liu, Huang, \& Zhu, 2013). It has been positively linked with different employee outcomes such as, job performance, and retention (Loi et al., 2006; Falkenburg \& Schyns, 2007; Tremblay et al., 2010). Organizational Commitment has even been exposed to be a more significant predictor of both turnover intention and actual turnover among different occupational employees, for instance, librarians (Millard, 2003) and call center employees in mobile organization (Zhou, Long, \& Wang, 2009). It is also studied having a significant negative relationship with quitting intention (Mulki, Jaramillo, \& Locander, 2008). Falkenburg and Schyns (2007) find both satisfaction and commitment to the organization are negatively allied with employee quitting intention.

Organizational commitment is also found having prominent consequence on nurse quitting intention (Lynn \& Redman, 2005). Wang et al. (2012) have asserted that nurse quitting intention is largely influenced by both job satisfaction and organizational commitment to the organization. An earlier study indicates organizational commitment explains $44.4 \%$ of the variance of nurse intention to quit (Ha \& Choi, 2002). Krash et al. (2005) and Kim et al. (2005) have asserted that organizational commitment helps the employees to be more attached with the organization and the consequential effect is their higher retention intention. The authors clarified that commitment enhances the self-responsibility among the employees to focus on the development of the organization as reciprocity. Therefore, from the previous literature support, it can be elucidated that organizational commitment is considered as an indispensable HR outcome that promotes other HR outcomes such as greater retention intention and lower quitting intention as well. Thus, following hypothesis can be proposed.

Hypotheses 5: Organizational commitment is negatively related with nurses' turnover intention.

Moreover, previous researchers support the use of organizational commitment as mediator between different variables (DeConinck \& Bachmann, 2011). In a study on HRM practices and employee exit voice, $\mathrm{Si}$ and $\mathrm{Li}$ (2012) find organizational commitment as mediator. The authors have revealed that employee perceived HRM practices together with higher organizational commitment declines employees exit voice and increases loyalty to the organization. In nursing study, organizational commitment is also found having mediation effect on quitting intention (Galletta, Portoghese, \& Battistelli, 2011). Armstrong-Stassen and Schlosser (2010) find organizational commitment fully mediates the relationship between perceived organizational support and quitting intention of older nurses in the hospital organization.

In summary, previous literature recommends there is a good reason to believe that organizational commitment is a potential mediator of perceived fairness of HRM practices on quitting intention. In other words, we are suggesting that perceived fairness of performance appraisal and promotion opportunity can have an indirect influence on nurses' quitting intention through organizational commitment. Therefore, we can propose the hypothesis for organizational commitment as mediator:

Hypothesis 6: Organizational commitment as mediator between performance appraisal fairness and nurse turnover intention.

Hypothesis 7: Organizational commitment as mediator between promotion opportunity and nurse turnover intention. 
Figure 1 shows the relationship among performance appraisal fairness, promotion opportunity, organizational commitment and nurses' turnover intention.

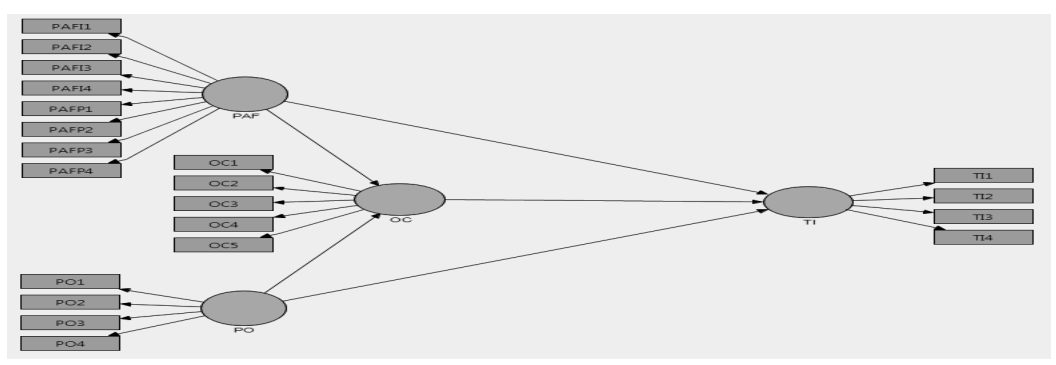

Figure 1. Conceptual framework

\section{Methodology}

\subsection{Sample}

This study targeted nurses who were working in large private hospitals in Bangladesh in the time of data collection, January to February, 2014. Bangladesh has approximately $60 \%$ private hospitals locating in Dhaka (Bangladesh Bureau of Statistics, 2012). For this reason, Dhaka was chosen as a suitable sampling frame. We selected two large private hospitals based on two criteria: (1) the number of bed capacity to be 200 beds and above and (2) years of operations for more than 5 years. A total of 450 questionnaires were distributed purposefully to the nurses and 175 were returned. Among these 175 questionnaires, 25 cases were deducted due to lack of information. In total, 150 questionnaires were found usable for data analysis with a response rate of $33 \%$. Smith, Scammon and Beck (1995) reveal that a response rate as low as $30 \%$ is 'reasonable' for the analysis. In the context of RMG industry in Bangladesh, Rubel and Kee (2014) have found only $29 \%$ response rate in their study. Moreover, in Partial Least Square (PLS) 100 sample size is sufficient for analysis (Hair, Black, Babin, Anderson, \& Tatham, 2010). Hence, the response rate of the present study was considered justified for analysis. The respondents were mainly in the age range of 22 to 35 years $(\mathrm{M}=30.54 ; \mathrm{SD}=2.57)$ and over half of them were female (88\%) and junior nurses (63\%). Approximately $88 \%$ had been employed for more than five years $(\mathrm{M}=7.5 ; \mathrm{SD}=1.79)$ and nearly $73 \%$ had a related degree or diploma degree. Only $4 \%$ were single.

\subsection{Measure}

Performance appraisal fairness was measured based on procedural and interactional fairness. Items of performance appraisal fairness of this study were adapted from the recognized scale of appraisal fairness. Nine items were considered to measure performance appraisal fairness. The items were adapted from Swiercz et al. (2012) originally developed by Folger and Konovsky (1989). The reliability for performance appraisal fairness ranges from 0.76 to 0.90 which is higher than the minimum accepted value 0.70 (Nunnally, 1978). We used a four-item scale (Liu, 2004) to assess promotion opportunity. The alpha value of this measurement is 0.83 .

We employed Gould-Williams and Davies (2005)'s 6 items scale to measure organizational commitment with high reliability (0.74). Finally, quitting intention was assessed using four items adapted from previous study by Wayne, Shore and Liden (1997). The authors demonstrated a high reliability (0.89) of the measurement. A five-point Likert's scale ranging from (1) strongly agree to (5) strongly disagree was employed to measure all the items representing each variable.

\section{Analysis and Results}

This study used partial least square path modeling technique to analyze the collected data. PLS is also known as the variance-based structural equation model consisting of factor analysis, correlation and regression. SPSS (Version 20) for Windows (SPSS, Chicago, IL) was employed to analyze the survey data to get the descriptive statistical output. Later, common method variance (CMV) was assessed to check the multicollinearity. When data are collected using a cross sectional survey method, CMV may be a problem (Podsakoff et al., 2003). To report this potential problem, Harman Single factor test was used. According to Podsakoff and Organ (1986) common method variance arises in the dataset if: 1) a single factor emerges from a factor analysis of all survey items, and 2) a single factor accounts for most of the common variance existing in the data. Therefore, in this concern an un-rotated factor analysis conducted on all measurement items extracted six factors with eigenvalues larger than or equal one. In this study total six factors accounted for 72.68 percent of the total variance and the 
first factor explains 29.88 percent. While, a single factor did not account for most of the variance, thus this study pretends that the CMV was not a main problem in this study.

\subsection{Measurement Model}

In this stage of data analysis, both convergent and discriminant validity were assessed to examine the measurement model. Convergent validity was calculated by measuring reliability, composite reliability (CR) and the average variance extracted (AVE). Reliability of items was measured by each item's loading on its corresponding construct. A rule of thumb suggests that the item loading should exceed 0.50 or higher (Hair et al., 2010). In this study, one item from performance appraisal fairness (PAF 9) and one item from organizational commitment (OC6) were deducted due to loading lower than the acceptable limit. On the other hand, all CRs and AVEs are recommended to be 0.70 and 0.5 or higher, respectively (Nunnally, 1978; Gefen, Straub, \& Boudreau, 2000). Table 1 shows that the both CR and AVEs exceeded 0.70 and 0.50 respectively with the lowest value being 0.90 (CR) for organizational commitment and 0.53 (AVE) for the performance appraisal fairness. Hence, all the conditions of convergent validity were fulfilled.

Further, Fornell and Larcker's formula was used to assess the discriminant validity between constructs that the square root of the AVE for each construct should be higher than the correlations between these constructs and all other constructs (Chin, 2010). This study finds the square root of AVE of all the diagonal values of the constructs were higher than the off-diagonal ones. As shown in Table 1 the calculated value of AVE exceeds the intercorrelations of the diagonal constructs with the other off-diagonal constructs ensuring adequate discriminant validity. Therefore, the results of the analysis can reveal that the measurement model of this study fulfills adequate convergent and discriminant validity.

Table 1. Item loading, scale reliability, AVE and CR

\begin{tabular}{lcccc}
\hline \multicolumn{1}{c}{ Constructs } & Items & Loading & CR & AVE \\
\hline Performance Appraisal & PAF1 & 0.672 & 0.897 & 0.525 \\
Fairness & PAF2 & 0.731 & & \\
& PAF3 & 0.548 & & \\
PAF4 & 0.619 & & \\
PAF5 & 0.742 & & \\
Promotion Opportunity & PAF6 & 0.808 & & \\
& PAF7 & 0.787 & & \\
& PAF8 & 0.844 & & \\
Organizational & PO1 & 0.702 & 0.911 & \\
Commitment & PO2 & 0.847 & & \\
& PO3 & 0.907 & & \\
& PO4 & 0.896 & & \\
turnover Intention & OC1 & 0.849 & 0.896 & \\
& OC2 & 0.873 & & \\
& OC3 & 0.623 & & \\
& OC4 & 0.822 & & \\
& OC5 & 0.793 & & \\
& TI1 & 0.920 & 0.937 & \\
\end{tabular}

This study also measured Goodness of Fit (GoF) using the formula suggested by Tenenhaus, Vinzi, Chatelin and Lauro (2005) and found the model had a large goodness of fit $(\mathrm{GoF}=0.620)$. According to Wetzels, Odekerken-Schroder and Van Oppen (2009) the value higher than 0.36 indicates global validation of the PLS model. In addition to evaluating the magnitude of the $\mathrm{R}^{2}$ values as a criterion of predictive accuracy, researchers need to examine the Stone-Geisser's $\mathrm{Q}^{2}$ value. This measure is an indicator of the model's predictive relevance. The $Q^{2}$ represents "a measure of how well observed values are reconstructed by the model and its parameter estimates" (Chin, 1998). For calculating predictive relevance, the stone-Geisser $\mathrm{Q}^{2}$ was considered. In this regard, the value redundancy (Red) in $\mathrm{Q}^{2}$ must be greater than zero (Chin, 2010). This study also fulfills the criteria for both organizational commitment (Red: 0.328 ) and quitting intention (Red: 0.487). 
Table 2. Discriminant validity table

\begin{tabular}{lcccccc}
\hline & Mean & SD & OC & PAF & PO & TI \\
\hline OC & 4.02 & 0.542 & 0.797 & & & \\
PAF & 3.91 & 0.718 & 0.596 & 0.725 & & \\
PO & 3.84 & 0.671 & 0.722 & 0.720 & 0.849 & \\
TI & 3.30 & 0.692 & -0.722 & -0.615 & -0.728 & 0.888 \\
\hline
\end{tabular}

Note: OC (Organizational Commitment), PAF (Performance Appraisal Fairness), PO (Promotion Opportunity), TI (Turnover Intention).

\subsection{Structural Model}

In analyzing the structural model, a bootstrapping method with 500 re-samples was deliberated to test for path significance (Chin, 1998). Table (3) and figure (2) explain all the path relationships of the framework. In the direct relationship between the variables, both the direct path of performance appraisal fairness to organizational commitment and promotion opportunity to organizational commitment were found statistically significant and the values were $(\beta=0.16, \mathrm{t}=1.79, \mathrm{p}<0.05)$ and $(\beta=0.607, \mathrm{t}=6.78, \mathrm{p}<0.01)$ respectively. Further, the direct effect from performance appraisal fairness to quitting intention and promotion opportunity to quitting intention also showed significant negative relationship and the values were $(\beta=-0.127, \mathrm{t}=1.83, \mathrm{p}<0.01),(\beta=-0.355, \mathrm{t}=$ $4.19, \mathrm{p}<0.01)$ respectively. Moreover the path from organizational commitment to quitting intention showed a negative and statistically significant relation $(\beta=-0.389, \mathrm{t}=5.16, \mathrm{p}<0.01)$.

Table 3. Result of partial squares path analysis

\begin{tabular}{lccc}
\hline \multicolumn{1}{c}{ Paths } & Std. Beta & t-Value & Decisions \\
\hline \multicolumn{1}{c}{ Direct Path } & & & \\
\hline Performance Appraisal Fairness $>$ Quitting intention & -0.127 & $1.83^{*}$ & $\mathrm{~S}$ \\
Promotion opportunity $>\quad$ turnover intention & -0.355 & $4.19^{* *}$ & $\mathrm{~S}$ \\
Performance Appraisal Fairness > Organizational commitment & 0.160 & $1.79^{*}$ & $\mathrm{~S}$ \\
Promotion opportunity $>\quad$ Organizational commitment & 0.607 & $6.78^{* *}$ & $\mathrm{~S}$ \\
Organizational commitment $>$ turnover intention & -0.389 & $5.16^{* *}$ & $\mathrm{~S}$ \\
\hline \multicolumn{1}{c}{ Indirect Path (Mediating Effect) } & & \\
\hline Performance Appraisal fairness > Organizational commitment > & -0.062 & $1.79^{*}$ & $\mathrm{~S}$ \\
turnover Intention & & \\
Promotion Opportunity $>$ Organizational commitment $>$ turnover & -0.24 & $3.55^{* *}$ & $\mathrm{~S}$ \\
Intention & & & \\
\hline Note: $* * \mathrm{p}<0.01, * \mathrm{p}<0.05$, (based on Two-tailed test with 500 bootstrapping) & & \\
\hline
\end{tabular}

Additionally, analysis was conducted to test the mediating effect of organizational commitment. Based on the three-step procedures recommended by Baron and Kenny (1986), it was obtained from the analysis that, performance appraisal fairness and promotion opportunity all had significant negative effects on quitting intention and organizational commitment. Furthermore, organizational commitment was also found significantly negatively related with nurse quitting intention. As a mediator, organizational commitment showed a significant relationship with both performance appraisal fairness-quitting intention $(\beta=-0.062, \mathrm{t}=1.79 \mathrm{p}<0.05)$ and promotion opportunity- quitting intention $(\beta=-0.24, \mathrm{t}=3.55, \mathrm{p}<0.01)$. In both cases of performance appraisal fairness and promotion opportunity, organizational commitment was considered as a partial mediator because the Variance Accounted For (VAF) found for performance appraisal fairness was 0.33 and for promotion opportunity was 0.40 . Researchers have justified, if the value of VAF is larger than 0.20 and less than 0.80 , the mediator can be characterized as a partial mediator (Hair, Hult, Ringle, \& Sarstedt, 2013).

\section{Discussion}

In this paper, we aim to advance our understanding of the effect of perceived fairness of performance appraisal and promotion opportunity on nurses quitting intention. Taken together, our results make few theoretical contributions. First, the relationship of performance appraisal fairness, promotion opportunity and turnover intention provide support for a negative relationship among them. Second, our study investigates the relationship among performance appraisal fairness, promotional opportunity and nurse quitting intention as mediated by organizational commitment. The results support the projected relationship. The results demonstrate both performance appraisal fairness and promotion opportunity are negatively related to nurse commitment to the 
organization and quitting intention. Further, the results of the study also prove the mediating effect of organizational commitment between the aforesaid relationships. These results highlight the importance of fairness in performance appraisal system and adequate promotion opportunity as a career development opportunity to get positive employee outcomes.

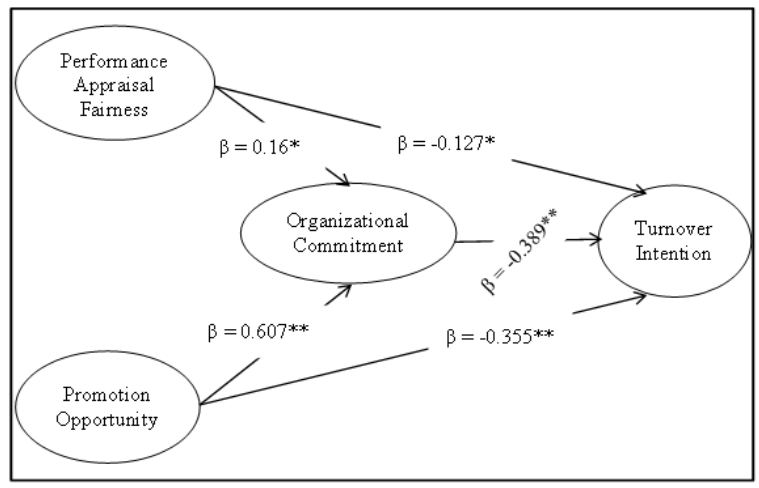

Figure 2. Structural Model

Armstrong-Stassen and Schlosser (2010) indicated the criteria for performance appraisal and its accuracy were necessary for nurses to enhance their attachment with work and loyalty to the organization. Dissatisfaction with performance appraisal lowers the employee feeling to the organization and thus, increases the chances of job search behavior (Whiting \& Kline, 2007). Consistent with these findings, the present study demonstrates when nurses perceive performance appraisal as fair, they are less likely to quit the organization.

On the contrary, the present study shows promotion opportunity is one of the strongest and imperative determinants of both employee behavioral and behavioral intention. The findings here thus support the view that promotion opportunity acts a decisive role in the employee's decision to leave the organization (Ali \& Baloch, 2010). Early researchers also find the consistent negative relationship between promotion opportunity and quitting intention of nurses (Tsai \& $\mathrm{Wu}, 2010$ ). These study findings exhibit positive perception regarding promotion and career development opportunity induces employees to be more devoted to the organization and thus enhances their sense of belongingness to the organization through minimizing turnover intention.

Therefore, this study highlighted specific HRM practices as stronger predictors of quitting intention. Beyond referring earlier research supports on the relationship between performance appraisal and quitting intention and promotion opportunity and quitting intention, this study contributes to provide empirical evidences of the influence of performance appraisal fairness and promotion opportunity on the nurse quitting intention. Additionally, as there is a gap in examining the relationship among performance appraisal fairness and promotion opportunity and turnover intention, this idea provides new insights to the existing knowledge of the HRM effect on employee outcomes as well.

Minimizing quitting intention is an important consequence of organizational commitment. Moreover, HRM practices positively affect employee commitment (Gould-Williams \& Davies, 2005). The present study provides evidences that both performance appraisal fairness and promotion opportunity contribute to better commitment that reduces the nurse quitting intention. The present study finds a significant relationship between performance appraisal fairness and organizational commitment, promotion opportunity and organizational commitment. The study outcomes simplify commitment of nurses will enhance if they find fairness in performance appraisal practices and satisfactory promotional opportunity. Previous researchers also reveal well-structured performance appraisal practices help the organization amplify the level of employee commitment and make them to be more organization oriented (Lynn \& Redman, 2005). Earlier literature also provides evidences of positive relationship between promotion opportunity and employee commitment and loyalty (Ha \& Choi, 2002). Yang et al. (2013) notice in prior study substantial attention has been given to examine commitment to identify the important attributes to make employee relationship with the organization. The same study also confirms the influence of commitment on employee performance and quitting intention (Yang et al., 2013). The present study also finds significant negative effect of commitment on nurse quitting intention. The finding can be interpreted as such nurse quitting intention will be lower when they show a higher level of commitment to the organization.

Moreover, this study considers the mediating effect of commitment between performance appraisal fairness-quitting intention and promotion opportunity-quitting intention relationship. The results of the structural 
model prove the significant mediating effect of organizational commitment between the aforesaid relationships. In both cases, commitment was found as a partial mediator. It is to say in another way that the direct as well as the indirect effect of performance appraisal fairness and promotion opportunity with the mediating effect of commitment facilitate nurse retention through reducing their quitting intention in the private medical hospitals of Bangladesh. Prior study on nurse quitting intention also confirmed the influence of organizational commitment as mediator and found both partial and full mediating effect of organizational commitment on quitting intention (Galletta et al., 2011). Therefore, the findings of this study corroborate early research findings as well.

However, this study suffers from the limitation of covering only the private hospitals. Public sector hospital nurses' intentions to quit may be influenced by different other factors, as the public and private sector are somewhat different from the perspective of HRM practices in Bangladesh. Further research is needed to consider both private and public sector hospital nurses' quitting intention to make comparative analysis. Such study may assert the relationship among performance appraisal fairness, promotion opportunity, organizational commitment and quitting intention in general. More studies are recommended to identify the effect of other HRM practices as individual and bundle on nurse quitting intention. These studies may help to prove the position of HRM practices in the hospital organizations in the developing country context.

\section{Conclusion}

The empirical findings obtained in this paper can be helpful to improve the employers' and practitioners' understanding of the effects of specific HRM practices on turnover intention in resolving the pressing phenomenon of high labor turnover rate in the workplaces. Hospital administrators are facing the biggest challenge to retain experienced and skilled workers specially nurse to provide high-quality health care service (Barnett, Namasivayam, \& Narudin, 2010). Our studies indicate how performance appraisal fairness and promotion opportunity influence nurses commitment and in turn it affects their thought of quitting. Managers in the hospitals must be aware, that stimulating a positive HRM practice leads to better scenario. Under such conditions, fairness perception of HRM practices has an even more positive influence on nurses' attitude (such as organizational commitment) and behavior (intention to quit). Fairness perception in HRM practices should be increased, as doing so positively impact their level of commitment and reduce their intent to quit the organization. For example, when nurses feel they are appraised fairly and they have career advancement scope through internal promotion policies, they are less likely to leave the organization. Thus, this study provides an evidence of the particular effect of specific component of HRM practices and its application on analyzing employee attitudinal and behavioral intention. Understanding so should give hospital management an insight about retaining nurses, and relieve them from turnover costs through taking steps before nurses with quitting intention become actual leaving nurses.

The results from our studies should be interpreted in light of potential limitations. First, in this paper we decided to include two major HRM practices-performance appraisal and promotion opportunity. Future research in exploring other HRM practices is required. Future, research should also focus on other factors such as, participation, suitable compensation, job security, support both from supervisor and organization and up-dated training and development that influence nurse level of commitment and intent to leave. Because HRM practices may be relevant for all employees in the hospitals, this population includes doctors constitute a reasonable sample for further testing hypotheses. Further, it is recommended to the future researchers to focus on other HRM practices and their implications on employee attitudes and behavior. Further, this study will give an insight to the future researches in other developing countries to assess the influence of both performance appraisal fairness and promotion opportunity on nurse commitment and turnover intention. Moreover, future researchers are also suggested to give their concentration on specific dimension of HRM practices and to analyze its impact, because individual dimension will provide information on their specific influence rather than investigating bundle HRM practices.

Therefore, the findings of this study emphasize the importance of specific HRM practices as significant predictors of nurse quitting intention in the healthcare organizations of developing country like Bangladesh. Ensuring performance appraisal fairness and promotion opportunity are effective strategies for increasing nurse commitment and reducing their quitting intentions. Thus, the study argues in favor of the application of specific HRM practice and its application to enhance the level of commitment as well as minimize turnover intention of nurses from the hospital organization.

\section{References}

Ahmed, S. M., Hossain, M. A., RajaChowdhury, A. M., \& Bhuiya, A. U. (2011). The health workforce crisis in Bangladesh: shortage, inappropriate skill-mix and inequitable distribution. Human Resource for Health, 
9(3). http://dx.doi.org/10.1186/1478-4491-9-3.

Alam, T., \& Shahi, M. (2012). Factors affecting job satisfaction, motivation and turnover rate of medical promotion officer (MPO) in pharmaceutical industry: a study based in Khulna city. Asian Business Review, 1(1), 126-131.

Ali, N., \& Baloch, Q. B. (2010). Job satisfaction and employees turnover intention: case study of NWFP Pakistan based banking sector. Institute of Interdisciplinary Business Research, 2(5), 39-66.

Ansari, M. A., Kee, D. M. H., \& Aafaqi, R. (2000). Fairness of human resource management practices, leader-member exchange, and intention to quit. Journal of International Business and Entrepreneurship, $8(1), 1-19$.

Armstrong-Stassen, M., \& Schlosser, F. (2010). When hospitals provide HR practices tailored to older nurses, will older nurses stay? It may depend on their supervisor. Human Resource Management Journal, 20(4), 375-390. http://dx.doi.org/10.1111/j.1748-8583.2010.00143.x

Barnett, T., Namasivayam, P., \& Narudin, D. A. A. (2010). A critical review of the nursing shortage in Malaysia. International Nursing Review, 57(1), 32-39. http://dx.doi.org/10.1111/j.1466-7657.2009.00784.x

Baron, R. M., \& Kenny, D. A. (1986). The moderator-mediator variable distinction in social psychological research: Conceptual, strategic, and statistical considerations. Journal of personality \& social psychology, 51(6), 1173-1182. http://dx.doi.org/10.1037/0022- 3514.51.6.1173

Bartram, T., Casimir, G., Djurkovic, N., Leggat, S. G., \& Stanton, P. (2012). Do perceived high performance work systems influence the relationship between emotional labour, burnout and intention to leave? A study of Australian nurses. Journal of Advanced Nursing, 68(7), 1567-1578. http://dx.doi.org/10.1111/j.13652648.2012.05968.x

BBS. (2012). Sctor wise explanation of the Industry. Dhaka: Bangladesh Bureau of Statistics. Retrieved from http://www.bbs.gov.bd

Beecroft, P. C., Dorey, F., \& Wenten, M. (2008). Turnover intention in new graduate nurses: a multivariate analysis. Journal of Advanced Nursing, 62(1), 41-52. http://dx.doi.org/10.1111/j.1365-2648.2007.04570.x

Blau, P. M. (1964). Exchange and power in social life. Transaction Publishers.

Boxall, P., \& Purcell, J. (2003). Strategy and human resource management. Industrial and Labor Relations Review, 57(1), 145-146.

Cai, C., \& Zhou, Z. (2009). Structural empowerment, job satisfaction, and turnover intention of Chinese clinical nurses. Nursing and Health Sciences, 11(4), 397-403. http://dx.doi.org/10.1111/j.1442-2018.2009.00470.x

Carson, P. P., Carson, K. D., Griffeth, R. W., \& Steel, R. P. (1994). Promotion and employee turnover: Critique, meta-analysis, and implications. Journal of Business and Psychology, 8(4), 455-466.

Chang, E. (1999). Career commitment as a complex moderator of organizational mommitment and thrnover Intention. Human Relations, 52(10), 1257-1278. http://dx.doi.org/10.1177/001872679905201002

Chaudhury, N., Hammer, J., Kremer, M., Muralidharan, K., \& Rogers, F. H. (2006). Missing in action: teacher and health worker absence in developing countries. The Journal of Economic Perspectives, 20(1), 91-116. Retrieved from http://www.jstor.org/stable/30033635

Chin, W. W. (1998). The partial least squares approach for structural equation modeling. In G. A. Marcoulides (Ed.), Modern methods for business research (pp. 295-336). Lawrence Erlbaum Associates.

Chin, W. W. (2010). How to write up and report PLS analyses. In V. Esposito Vinzi, W. W. Chin, J. Henseler, \& H. Wang (Eds.), Handbook of partial least squares (pp. 655-690). Springer, New York. http://dx.doi.org/10.1007/978-3-540-32827-829

Collins, C. J., \& Clark, K. D. (2003). Strategic human resource practices, top management team social networks, and firm performance: The role of human resource practices in creating organizational competitive advantage. Academy of management Journal, 46(6), 740-751. http://dx.doi.org/10.2307/30040665

DeConinck, J. B., \& Bachmann, D. P. (2011), Organizational commitment and turnover intentions of marketing managers, Justice at the millennium: a meta-analytic review of 25 years of organizational justice research. Journal of applied business research (JABR), 10(3), 87-95.

DeNisi, A. S., \& Pritchard, R. D. (2006). Performance appraisal, performance management and improving individual performance: A motivational framework. Management and Organization Review, 2(2), 253-277. 
http://dx.doi.org/10.1111/j.1740-8784.2006.00042.x

Dessler, G. (2009) ). Human resource management. Pearson Prentice Hall.

El-Jardali, F., Dimassi, H., Dumit, N., Jamal, D., \& Mouro, G. (2009). A national cross-sectional study on nurses' intent to leave and job satisfaction in Lebanon: Implications for policy and practice. BMC nursing, 8(1), 3 . http://dx.doi.org/10.1186/1472-6955-8-3

Falkenburg, K., \& Schyns, B. (2007). Work satisfaction, organizational commitment and withdrawal behaviours. Management Research News, 30(10), 708-723. http://dx.doi.org/10.1108/09596111011053819

Folger, R., \& Konovsky, M. A. (1989). Effects of procedural and distributive justice on reactions to pay raise decisions. Academy of Management Journal, 32(1), 115-130. http://dx.doi.org/10.2307/256422

Galletta, M., Portoghese, I., \& Battistelli, A. (2011). Intrinsic motivation, job autonomy and turnover intention in the Italian healthcare: the mediating role of affective commitment. Journal of Management Research, 3(2), 1-19. http://dx.doi.org/10.5296/jmr.v3i2.619

Gefen, D., Straub, D. W., \& Boudreau, M. C. (2000). Structural equation modeling and regression: Guidelines for research practice. Communications of the Association for Information Systems Citeseer, 4(7), 1-77.

Gould-Williams, J., \& Davies, F. (2005). Using social exchange theory to predict the effects of HRM practice on employee outcomes: An analysis of public sector workers. Public Management Review, 7(1), 1-24. http://dx.doi.org/10.1080/1471903042000339392.

Guchait, P., \& Cho, S. (2010). The impact of human resource management practices on intention to leave of employees in the service industry in India: the mediating role of organizational commitment. The International Journal of Human Resource Management, 21(8), 1228-1247. http://dx.doi.org/10.1080/09585192.2010.483845

Ha, N. S., \& Choi, J. (2002). The relationship among leadership styles of nurse managers, job satisfaction, organizational commitment, and turnover intention. Journal of Korean Academy of Nursing, 32(6), 812-822.

Haines, V. Y., Jalette, P., \& Larose, K. (2010). The influence of human resource management practices on employee voluntary turnover rates in the Canadian non-governmental sector. Industrial and Labor Relations Review, 63(2), 228-246.

Hair, J. F. Jr., Hult, G. T. M., Ringle, C., \& Sarstedt, M. (2013). A primer on partial least squares structural equation modeling (PLS-SEM). SAGE Publications, Incorporated, London.

Hair, J. F., Black, W. C., Babin, B. J., Anderson, R. E., \& Tatham, R. L. (2010). Multivariate data analysis: A global perspective (7th ed.). Upper Saddle River, NJ: Pearson Education.

Hayes, L. J., O’Brien-Pallas, L., Duffield, C., Shamian, J., Buchan, J., Hughes, F., ... Stone, P. W. (2006). Nurse turnover: a literature review, International journal of nursing studies, 43(2), 237-263. http://dx.doi.org/10.1016/j.ijnurstu.2005.02.007

Holtom, B. C., Mitchell, T. R., Lee, T. W., \& Eberly, M. B. (2008). 5 Turnover and Retention Research: A Glance at the Past, a Closer Review of the Present, and a Venture into the Future. The Academy of Management Annals, 2(1), 231-274. http://dx.doi.org/10.1080/19416520802211552

Homans, G. C. (1958). Social behavior as exchange. American journal of sociology, 63(6), 597-606. Retrieved from http://www.jstor.org/stable/2772990

Hossain, D. (2008). Nurses' satisfaction on job performance provided in public and private hospitals. In Business Administration. Masters Northern University, Bangladesh, Dhaka, Bangladesh.

Hwang, J. I., \& Chang, H. (2009). Work climate perception and turnover intention among Korean hospital staff. International Nursing Review, 56(1), 73-80. http://dx.doi.org/10.1111/j.1466-7657.2008.00641.x

Ikramullah, M., Shah, B., Khan, S., Hassan, F. S. U., \& Zaman, T. (2012). Purposes of performance appraisal system: A perceptual Sstudy of Civil servants in district dera Ismail Khan Pakistan. International Journal of Business and Management, 7(3), 142-151. http://dx.doi.org/10.5539/ijbm.v7n3p142

Jawahar, I. M. (2007). The influence of perceptions of fairness on performance appraisal reactions. Journal of Labor Research, 28(4), 735-754. http://dx.doi.org/10.1007/s12122-007-9014-1.

Joarder, M. H. R. (2012). The role of HRM practices in predicting faculty turnover intention: empirical evidence from private universities in Bangladesh. The South East Asian Journal of Management, 5(2), 159-178. 
Karsh, B., Booske, B. C., \& Sainfort, F. (2005). Job and organizational determinants of nursing home employee commitment, job satisfaction and intent to turnover. Ergonomics, 48(10), 1260-1281. http://dx.doi.org/10.1080/00140130500197195

Kee, D. M. H., Ansari, M. A., \& Aafaqi, R. (2004). Fairness of human resource management practices, leader-member exchange and organizational commitment. Asian Academy of Management Journal, 9(1), 99-120.

Kehoe, R. R., \& Wright, P. M. (2013). The impact of high-performance human resource practices on employees' attitudes and behaviors. Journal of Management, 39(2), 366-391. http://dx.doi.org/10.1177/01492063 10365901

Kiekbusch, R., Price, W., \& Theis, J. (2003). Turnover predictors: causes of employee turnover in sheriff-operated jails. Criminal Justice Studies, 16(2), 67-76. http://dx.doi.org/10.1080/088843103200011 5600 .

Kim, S. (2012). The impact of human resource management on state government IT employee turnover intentions. Public Personnel Management, 41(2), 257-279. http://dx.doi.org/10.1177/009102601204100204

Kim, W. G., Leong, J. K., \& Lee, Y. K. (2005). Effect of service orientation on job satisfaction, organizational commitment, and intention of leaving in a casual dining chain restaurant. International Journal of Hospitality Management, 24(2), 171-193. http://dx.doi.org/10.1016/j.ijhm.2004.05.004

Kingma, M. (2001). Nursing migration: global treasure hunt or disaster-in-the making? Nursing Inquiry, 8(4), 205-212. http://dx.doi.org/10.1046/j.1440-1800.2001.00116.x

Korsgaard, M. A., \& Roberson, L. (1995). Procedural justice in performance evaluation: The role of instrumental and non-instrumental voice in performance appraisal discussions. Journal of management, 21(4), 657-669. http://dx.doi.org/10.1177/014920639502100404

Kosteas, V. D. (2011). Job satisfaction and promotions. Industrial Relations: A Journal of Economy and Society, 50(1), 174-194. http://dx.doi.org/10.1111/j.1468-232X.2010.00630.x

Lau, C. M., \& Moser, A. (2008). Behavioral effects of nonfinancial performance measures: the role of procedural fairness. Behavioral Research in Accounting, 20(2), 55-71. http://dx.doi.org/10.2308/bria.2008.20.2.55

Lepak, D., \& Gowan, M. (2010). Human Resource Management - Managing employees for competitive advantage. London: Pearson Education LTD.

Liu, C., Zhang, L., Ye, W., Zhu, J., Cao, J., Lu, X., \& Li, F. (2012). Job satisfaction and intention to leave: a questionnaire survey of hospital nurses in Shanghai of China. Journal of clinical nursing, 21(1-2), 255-263. http://dx.doi.org/10.1111/j.1365-2702.2011.03766.x

Liu, W. (2004). Perceived organizational support: Linking human resource management practices with important work outcomes (Doctoral Dissertation). University of Maryland.

Loi, R., Hang-Yue, N., \& Foley, S. (2006). Linking employees' justice perceptions to organizational commitment and intention to leave: The mediating role of perceived organizational support. Journal of Occupational and Organizational Psychology, 79(1), 101-120. http://dx.doi.org/10.1348/096317905X39657

Lynn, M. R., \& Redman, R. W. (2005). Faces of the nursing shortage: influences on staff nurses' intentions to leave their positions or nursing. Journal of Nursing Administration, 35(5), 264-270.

McNeese-Smith, D. (1996). Increasing employee productivity, job satisfaction, and organizational commitment. Hospital \& Health Services Administration, 41(2), 160-175.

McNeese-Smith, D. K., \& Nazarey, M. (2001). A nursing shortage: Building organizational commitment among nurses. Journal of Healthcare Management, 46, 173-187.

Meyer, J. P., \& Allen, N. J. (1991). A three-component conceptualization of organizational commitment. Human resource management review, 1(1), 61-89. http://dx.doi.org/10.1016/1053-4822(91)90011-Z.

Millard, D. M. (2003). Why do we stay? Survey of long-term academic librarians in Canada. portal: Libraries and the Academy, 3(1), 99-111.

Morrell, K. (2005). Towards a typology of nursing turnover: the role of shocks in nurses' decisions to leave. Journal of Advanced Nursing, 49(3), 315-322. http://dx.doi.org/10.1111/j.1365-2648.2004.03290.x

Mowday, R. T., Steers R. M., \& Porter, L. M. (1979). The measurement of organizational commitment. Journal of Organizational Behavior, 14, 224-47. http://dx.doi.org/10.1016/0001-8791(79)90072-1 
Mulki, J. P., Jaramillo, J. F., \& Locander, W. B. (2008). Effect of ethical climate on turnover intention: Linking attitudinal-and stress theory. Journal of Business Ethics, 78(4), 559-574. http://dx.doi.org/10.1007/s10551007-9368-6

Naveed, A., Usman, A., \& Bushra, F. (2011). Promotion: a predictor of job satisfaction a study of glass industry of Lahore (Pakistan). International Journal of Business and Social Science, 2(16), 301-305.

Nogueras, D. J. (2005). Occupational commitment, education, and experience as a predictor of intent to leave the nursing profession. Nursing economic, 24(2), 86-93

Nunnally, J. C. (1978). Psychometric Theory. McGraw-Hill, New York.

Rahman, S. M., Ali, N. A., Jennings, L., Seraji, M. H. R., Mannan, I., Shah, R., Al-Mahmud, A. B., .. Das, M. K. (2010). Research Factors affecting recruitment and retention of community health workers in a newborn care intervention in Bangladesh. Human Resource for Health, 8(12), 2-14. http://dx.doi.org/10.1186/14784491-8-12

Redman, T., Snape, E., Thompson, D., \& Yan, F. K. C. (2000). Performance appraisal in an NHS hospital. Human Resource Management Journal, 10(1), 48-62. http://dx.doi.org/10.1111/j.1748-8583.2000.tb00013.x

Roberson, Q. M., \& Stewart, M. M. (2006). Understanding the motivational effects of procedural and informational justice in feedback processes. British Journal of Psychology, 97(3), 281-298. http://dx.doi.org/10.1348/000712605X80146

Rosen, J., Stiehl, E. M., Mittal, V., \& Leana, C. R. (2011). Stayers, leavers, and switchers among certified nursing assistants in nursing homes: a longitudinal investigation of turnover intent, staff retention, and turnover. The Gerontologist, 51(5), 597-609. http://dx.doi.org/10.1093/geront/gnr025

Rosen, S. (1986). The Theory of Equalizing Differences. NorthHolland: Oxford and Tokyo.

Rubel, M. R. B., \& Kee, D. M. H. (2013). High performance work practice and employee turnover intention in South Asian Countries. International Business Management, 7(6), 452-462. http://dx.doi.org/10.3923/ ibm.2013.452.462

Rubel, M. R. B., \& Kee, D. M. H. (2014). Quality of work life and employee performance: Antecedent and outcome of job satisfaction in Partial Least Square (PLS). World Applied Sciences Journal, 31(4), 456-467. http://dx.doi.org/10.5829/idosi.wasj.2014.31.04.142.

Salleh, M., Amin, A., Muda, S., \& Halim, M. A. S. A. (2013). Fairness of Performance Appraisal and Organizational Commitment. Asian Social Science, 9(2), 121-128. http://dx.doi.org/10.5539/ass.v9n2p121

Scott, S. G., \& Einstein, W. O. (2001). Strategic performance appraisal in team-based organizations: One size does not fit all. The Academy of Management Executive, 15(2), 107-116. http://dx.doi.org/10.5465/ AME.2001.4614990

Smith, J. A., Scammon, D. L., \& Beck, S. L. (1995). Using patient focus groups for new patient services. The Joint Commission journal on quality improvement, 21(1), 22-31.

Swiercz, P. M., Bryan, N. B., Eagle, B. W., Bizzotto, V., \& Renn, R. W. (2012). Predicting employee attitudes and performance from perceptions of performance appraisal fairness. Business Renaissance Quarterly, 7(1), 25-46.

Tenenhaus, M., Vinzi, V. E., Chatelin, Y. M., \& Lauro, C. (2005). PLS path modeling. Computational statistics \& data analysis, 48(1), 159-205. http://dx.doi.org/10.1016/j.csda.2004.03.005

Tourigny, L., Baba, V. V., Han, J., \& Wang, X. (2013). Emotional exhaustion and job performance: the mediating role of organizational commitment. The International Journal of Human Resource Management, 24(3), 514-532. http://dx.doi.org/10.1080/09585192.2012.694109

Tremblay, M. Cloutier, J. Simard, G. Chênevert, D., \& Vandenberghe, C. (2010). The role of HRM practices, procedural justice, organizational support and trust in organizational commitment and in-role and extra-role performance. The International Journal of Human Resource Management, 21(3), 405-33. http://dx.doi.org/ $10.1080 / 09585190903549056$.

Tsai, Y., \& Wu, S. W. (2010). The relationships between organisational citizenship behaviour, job satisfaction and turnover intention. Journal of clinical nursing, 19(23-24), 3564-3574. http://dx.doi.org/10.1111/ j.1365-2702.2010.03375.x

Wang, L., Tao, H., Ellenbecker, C. H., \& Liu, X. (2012). Job satisfaction, occupational commitment and intent to 
stay among Chinese nurses: a cross-sectional questionnaire survey. Journal of Advanced Nursing, 68(3), 539-549. http://dx.doi.org/10.1111/j.1365-2648.2011.05755.x

Watch, G. G. H. (2005). Global Health Watch 2005-2006: An alternative world health report. London and New York.

Wayne, S. J., Shore, L. M., \& Liden, R. C. (1997). Perceived organizational support and leader-member exchange: A social exchange perspective. Academy of Management Journal, 40(1), 82-111. http://dx.doi.org/10.2307/257021

Wetzels, M., Odekerken-Schroder, G., \& Van Oppen, C. (2009). Using PLS path modeling for assessing hierarchical construct models: guidelines and empirical illustration. MIS quarterly, 33(1), 177-195.

Whiting, H. J., \& Kline, T. J. B. (2007). Testing a model of performance appraisal fit on attitudinal outcomes. The Psychologist-Manager Journal, 10(2), 127-148. http://dx.doi.org/10.1080/10887150701451288

Yalabik, Z. Y., Chen, S., Lawler, J., \& Kim, K. (2008). High performance work system and organizational turnover in East and Southeast Asian countries. Industrial Relations: a journal of economy and society, 47(1), 145-152. http://dx.doi.org/10.1111/j.1468-232X.2008.00509.x

Yang, J., Liu, Y. Huang, C., \& Zhu, L. (2013). Impact of empowerment on professional practice environments and organizational commitment among nurses: A structural equation approach. International Journal of Nursing Practice, 19(S1), 44-55. http://dx.doi.org/10.1111/ijn.12016

Zafirovski, M. (2005). Social exchange theory under scrutiny: A positive critique of its economic-behaviorist formulations. Electronic Journal of Sociology, 2, 1-40.

Zhou, H., Long, L. R., \& Wang, Y. Q. (2009). What is the most important predictor of employees' turnover intention in Chinese call centre: job satisfaction, organisational commitment or career commitment? International Journal of Services Technology and Management, 12(2), 129-145. http://dx.doi.org/10.1504/IJSTM.2009.025231

\section{Copyrights}

Copyright for this article is retained by the author(s), with first publication rights granted to the journal.

This is an open-access article distributed under the terms and conditions of the Creative Commons Attribution license (http://creativecommons.org/licenses/by/3.0/). 